タンパク質制限給餌により血液成分に 改善がみられた牛クローディンー16欠損症の一例

安中篤史 池田浩希 飯塚優介 長縄直樹 安藤貴朗 大塚浩通 朴 天鎬 星 史雄 小山田敏文 渡辺大作

北里大学獣医学部獣医学科

\title{
Restriction of protein intake improved blood component levels in a bovine with Claudin-16 deficiency
}

\author{
A. Annaka, H. Ikeda, Y. Iizuka, N. Naganawa, T. Ando, \\ C-H. Park, H. Ohtsuka, F. Hoshi, T. Oyamada, D. Watanabe
}

School of Veterinary Medicine, Kitasato University

\begin{abstract}
要 約 クローディン-16(CL-16) 久損症の9ケ月齢の黒毛和雌牛に対して、腎臓への負担を軽減 する目的で粗飼料のみによるタンパク質制限給餌をおこなった。初診時には軽度の貧血と跛行、血漿尿 素窒素（UN）、クレアチニン（Crea）、総コレステロール（T-chol）およびビタミンA（VA）濃度が高 值を示したが、第40病日では血漿UNとT-chol は著しく減少し、血漿CreaとVA濃度は低下したものの 依然高值を示した。貧血および跛行は改善した。本症例ではタンパク質摂取量を制限することで、血液 成分を改善することができたと考えられた。

—キーワード：牛、クローディン-16欠損症、過長蹄、低タンパク質飼料、腎不全
\end{abstract}

家畜臨床誌 $30(1): 10-15,2007$

ABSTRACT A 9 -month-old Japanese black bovine with Claudin-16 (CL-16) deficiency was maintained on a low-protein diet to reduce the load on the kidneys. At the time of the first examination, the animal had slight anemia and lameness, and high plasma levels of urea nitrogen (UN), creatinine (Crea), total cholesterol (T-chol) and vitamin A (VA). After 40 days on the low protein diet, the clinical symptoms improved, and the values of plasma biochemical variables decreased. But Crea and VA levels remained high, although showing some decrease. These results suggest that a low protein diet might improve blood component levels in cattle with CL-16 deficiency.

Key Words : cattle, Claudin-16 deficiency, long hooves, low-protein diet, renal failure

E-mail : dwatanab@vmas.kitasato-u.ac.jp 


\section{緒 言}

牛クローディン-16（CL-16） 欠損症は、発育不良や過 長蹄を伴う常染色体劣性の遺伝性腎疾患であり、ほとん どが最終的には尿毒症となり死の転帰をとることから経 済的損失が大きい疾病である $[7,8,11,12,19,20]$ 。 CL-16夕ンパク質は牛では腎臓のヘンレの上行脚におけ る太いワナのタイトジャンクションにのみ存在が確認さ れており [13]、その久損により尿細管の低形成や間質 性腎炎がみられる $[8,14,17,20]$ 。

CL-16欠損症では腎機能が障害される結果、血液中の 尿素窒素（UN）およびクレアチニン（Crea）濃度が上 昇し、最終的に尿毒症を起こす $[7,8,11,14,17,20]$ 。 臨床徴候の発現時期は一定ではなく、1 ケ月齢から 3 回 出産した牛まで様々な報告があるが、多くの症例は出生 時に異常がみられず、加齢に伴って発育不良や過長蹄な ど症状が発現している $[7,8,11,14,19,20]$ 。症状発現 の時期がばらつく要因について検討した報告はなく、ま た栄養状態と症状の関連を調査した報告もみられない。 ヒト $[10,16]$ 、犬 $[2,3,5,15,18]$ および猫 [1] の慢性腎疾患においては、タンパク質やリンを制限する 食事または食餌療法が推奨されている。タンパク質およ びリン制限の有用性としては、尿毒症症状の改善、腎機 能低下の抑制、高リン血症と高カリウム血症の是正があ げられる $[1,10,16,18]$ 。ヒおおび犬では、タンパク 質およびリンの摂取制限が尿毒症の進行を抑制するとい う報告が多いが $[2,3,5,10,15,16]$ 、延命効果や腎機 能の改善効果については一定の見解は得られていない $[3,10]$ 。また、牛の遺伝性腎疾患に対して食飰療法を 行った報告はみられない。このため、CL-16欠損牛の一 症例に対する低タンパク質飼料給餌の影響を調査したの でその概要を報告する。

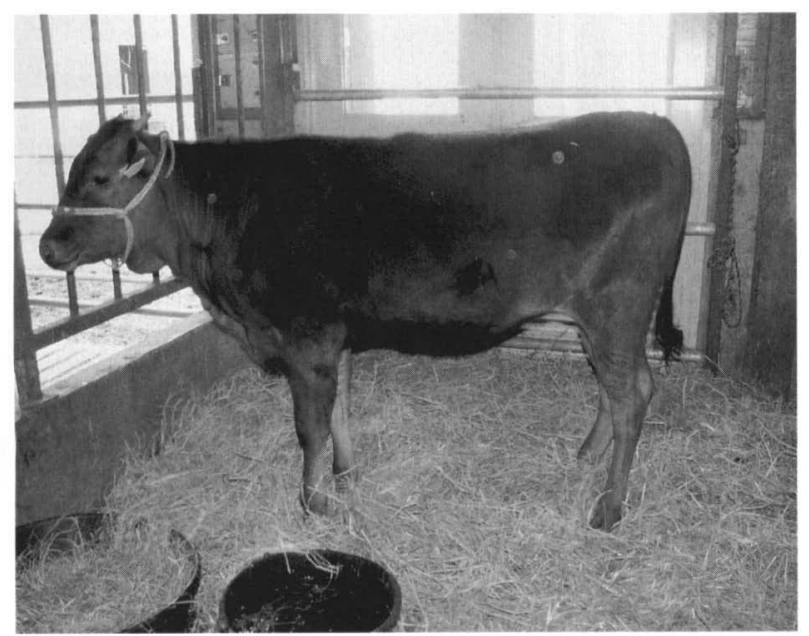

図 1. 来院時の症例
症 例

症例は、臨床症状と血統からCL-16欠損症が疑われ、 遺伝子検査により Type 1 のCL-16欠損症と診断され本学 付属動物病院に提供された 9 ケ月㱓の黒毛和種雌牛で (図 1 )、来院時の体重は253kg とほほ正常発育であった。

タンパク質の摂取制限：本症例では事前に腎機能障害 があることが判明していたことから、入院当初より腎臓 の負担を軽減させるために粗飼料のみによる低タンパク 質飼料で飼育（以下、タンパク質制限給飭）した。飼料 計算は、来院前の飼料は来院直前の給与飼料を聞き取り 調査し、来院前および来院後の給与飼料、給与量、飼料 成分量および充足率について表 1 に示した。なお、飼料

表 1. 症例の来院前後の給与飼料と飼料設定

\begin{tabular}{lcc}
\hline 給与飼料と給与量 & & \\
\hline 給与飼料 & 来院前 $(\mathrm{kg})$ & 来院後 $(\mathrm{kg})$ \\
\hline \hline 稲ワラ & 1.0 & 0 \\
ルーサン乾草 & 0.8 & 0.8 \\
オーツヘイ & 0 & 1.0 \\
自家乾草 & 0 & 2.0 \\
チモシー乾草 & 0 & 1.0 \\
子牛配合 & 3.3 & 0 \\
フスマ & 1.5 & 0 \\
\hline
\end{tabular}

飼料成分と給与量、充足率

\begin{tabular}{lrr}
\hline & 来院前** & 来院後 \\
\hline \hline 体重 $(\mathrm{kg})^{*}$ & 253 & 253 \\
$\mathrm{DG}^{* * *}$ & 0.90 & 0.10 \\
$\mathrm{TDN}$ 給与量 $(\mathrm{kg})$ & 3.96 & 2.04 \\
$\mathrm{TDN}$ 充足率 & 1.01 & 0.98 \\
$\mathrm{DCP}$ 給与量 $(\mathrm{g})$ & 676 & 255 \\
$\mathrm{DCP}$ 充足率 & 1.73 & 1.46 \\
乾物給与量 $(\mathrm{kg})$ & 5.79 & 5.56 \\
乾物充足率 & 1.04 & 1.31 \\
VA給与量 $(\mathrm{IU})$ & 20,800 & 18,000 \\
$\mathrm{VA}$ 充足率 & 1.94 & 1.68 \\
$\mathrm{Ca}$ 給与量 $(\mathrm{g})$ & 22 & 23 \\
$\mathrm{Ca}$ 充足率 & 0.78 & 2.33 \\
$\mathrm{P}$ 給与量 $(\mathrm{g})$ & 29 & 9 \\
$\mathrm{P}$ 充足率 & 1.94 & 9.96 \\
$\mathrm{Mg}$ 給与量 $(\mathrm{g})$ & 18 & 56 \\
乾物中NDF $(\%)$ & 37 & 9 \\
\hline
\end{tabular}

* 来院前の給与飼料は直前の給与量で計算した。

** 来院前体重は来院時の体重とし、充足率を求めた。

*** DG ; dairy gainは飼料計算から発育可能な数值を設定し た。充足率は体重、DGをもとに日本飼養標準 肉用牛 （2000年版）により求めた。 
表 2. 症例の血液検査所見

\begin{tabular}{lrc}
\hline \multicolumn{1}{c}{ 項 $\quad$ 目 } & 第 1 病日 & 第 2 病日 \\
\hline \hline $\mathrm{RBC}\left(10^{4} / \mu \mathrm{l}\right)$ & 707 & 987 \\
$\mathrm{Hb}(\mathrm{g} / \mathrm{dl})$ & 9.1 & 13.0 \\
$\mathrm{Ht}(\%)$ & 26.2 & 36.8 \\
$\mathrm{MCV}(\mathrm{fl})$ & 37.1 & 37.3 \\
$\mathrm{MCH}(\mathrm{pg})$ & 12.9 & 13.2 \\
$\mathrm{MCHC}(\mathrm{g} / \mathrm{dl})$ & 34.7 & 35.3 \\
$\mathrm{PLT}\left(10^{4} / \mu \mathrm{l}\right)$ & 44.6 & 63.2 \\
$\mathrm{WBC}\left(10^{2} / \mu \mathrm{l}\right)$ & 77 & 69 \\
$\operatorname{Band}(/ \mu \mathrm{l})$ & 154 & 0 \\
$\operatorname{Seg}(/ \mu \mathrm{l})$ & 1,925 & 2,277 \\
Lymp $(/ \mu \mathrm{l})$ & 5,198 & 4,278 \\
Mono $(/ \mu \mathrm{l})$ & 231 & 311 \\
Eosin $(/ \mu \mathrm{l})$ & 154 & 35 \\
Baso $(/ \mu \mathrm{l})$ & 39 & 35 \\
\hline
\end{tabular}

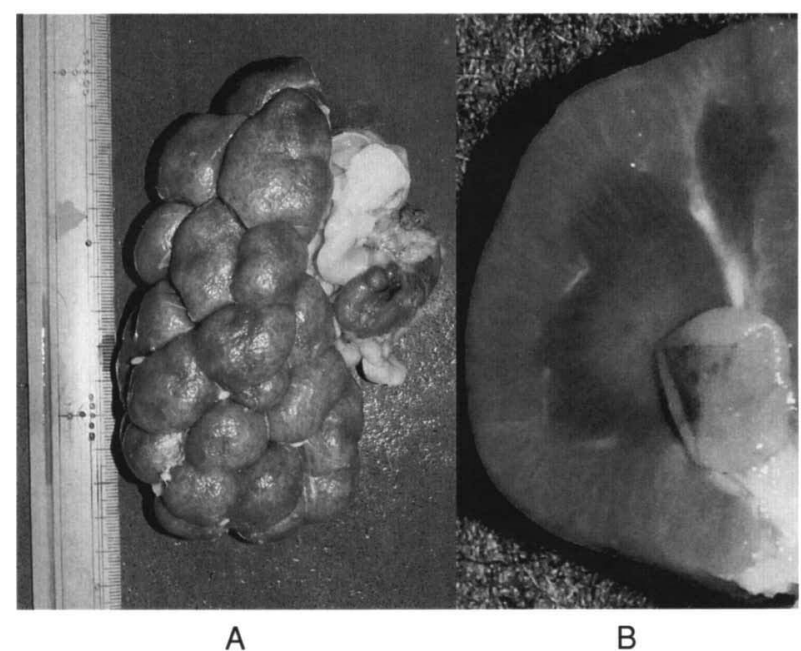

図 2. 腎臟の病理解剖所見

$\mathrm{A}$ ：左腎; 腎表面は粗造で褐色を呈している

B：右腎横断面の拡大像；卑湿に線状白色斑がび 慢性に認められる

表 3. 症例の血液生化学検査値の推移

\begin{tabular}{|c|c|c|c|c|c|c|}
\hline 検査項目 & 第 1 病日 & 第10病日 & 第18病日 & 第26病日 & 第30病日 & 第40病日 \\
\hline $\mathrm{TP}(\mathrm{g} / \mathrm{dl})$ & 6.2 & 6.6 & 6.9 & 6.6 & 6.7 & 6.4 \\
\hline $\operatorname{ALB}(\mathrm{g} / \mathrm{dl})$ & 3.7 & 3.8 & 3.7 & 3.6 & 3.6 & 3.5 \\
\hline $\mathrm{A} / \mathrm{G}$ & 1.48 & 1.36 & 1.16 & 1.20 & 1.16 & 1.21 \\
\hline Glu (mg/dl) & 92 & 82 & 75 & 72 & 92 & 71 \\
\hline T-chol (mg/dl) & 201 & 150 & 98 & 61 & 62 & 66 \\
\hline $\mathrm{UN} \quad(\mathrm{mg} / \mathrm{dl})$ & 79.6 & 58.4 & 42.3 & 32.7 & 26.8 & 15.7 \\
\hline Crea (mg/dl) & 3.6 & 3.3 & 3.3 & 3.1 & 2.8 & 2.9 \\
\hline VA（IU/dl） & 483 & 418 & 322 & 330 & 333 & 283 \\
\hline AST (IU/1) & 110 & 83 & 98 & 78 & 82 & 88 \\
\hline$\gamma-\mathrm{GT}(\mathrm{IU} / 1)$ & 11 & 15 & 16 & 5 & 16 & 12 \\
\hline $\mathrm{TB}$ (mg/dl) & 0.34 & 0.25 & 0.26 & 0.21 & 0.24 & 0.26 \\
\hline $\mathrm{DB}(\mathrm{mg} / \mathrm{dl})$ & 0.06 & 0.05 & 0.04 & 0.03 & 0.03 & 0.05 \\
\hline LDH（IU/1） & 3576 & 1055 & 1064 & 1037 & 3308 & 1055 \\
\hline CPK (IU/1) & 608 & 171 & 231 & 229 & 234 & 292 \\
\hline iP (mg/dl) & 7.0 & 8.6 & 6.7 & 7.2 & 7.5 & 6.9 \\
\hline $\mathrm{Ca}(\mathrm{mg} / \mathrm{dl})$ & 9.9 & 12.0 & 11.6 & 11.6 & 11.9 & 10.6 \\
\hline $\mathrm{Mg}$ (mg/dl) & 2.9 & 2.3 & 2.2 & 2.1 & 1.9 & 1.4 \\
\hline
\end{tabular}

$\mathrm{TP}$; 総タンパク質、ALB；アルブミン、Glu；血糖、T-chol；総コレステロール、UN ; 尿素窒素、Crea；クレアチニン、 $\mathrm{VA} ;$ ビタミンA、AST ; アスパラギン酸アミノトランスフェラーゼ、 $\gamma-\mathrm{GT} ； \gamma-$ ダルタミルトランスペプチダーゼ、 $\mathrm{TB}$; 総ビリルビン、 $\mathrm{DB}$; 直接ビリルビン、 $\mathrm{LDH}$; 乳酸脱水素酵素、 $\mathrm{CPK}$; クレアチンホスホキナーゼ、 $\mathrm{iP}$; 無機リン、 $\mathrm{Ca} ;$ カルシウム、 $\mathrm{Mg}$ ；マグネシウム

計算は日本飼養標準 肉用牛（2000年版；中央畜産会、 東京）に基づいておこない、来院前体重は来院時体重と 同じとして充足率を求めた。来院前と来院後で一日当た りの可消化粗タンパク質量 (DCP) は676gから255gに、 可消化養分総量（TDN）は $3.9 \mathrm{~kg}$ から $2.0 \mathrm{~kg}$ に、VA供給 量は20,800IUから18,000IUとなった。また、リンは29g
から $9 \mathrm{~g}$ に大き減少し、結果的にリン制限給餌となっ た。このタンパク質制限給餌により、dairy gain (DG) の設定は来院前の $0.9 \mathrm{~kg}$ から来院後は $0.1 \mathrm{~kg}$ となったが、 増体を低く設定したため、可消化養分総量、可消化タン パク質およびミネラルなどの各栄養成分は体重を維持す るには十分な充足率であった。 
臨床症状：初診時は体温 $39.4^{\circ} \mathrm{C}$ 、心拍数 80 回/分、呼 吸数30回/分で、軽度の跛行および軽度の過長蹄がみら れた。タンパク質制限給餌をおこなったところ、跛行は 次第に軽減し、第14病日以降では消失した。来院時に低 下していた食欲䇽よび活力も次第に旺盛になり、第 4 病 日以降は与えた飼料を完食した。入院期間中の体重変動 はなく、第 49 病日に安楽殺した。

血液検査所見：初診時にへモグロビン、ヘマトクリッ 卜值は軽度の低値を示し、白血球百分比には顕著な異常 を認めなかった。第30病日には貧血が改善した（表 2 )。 血液生化学所見では、初診時に血漿UN、Crea㧍よび総 コレステロール（T-chol）濃度の中等度の増加とビ夕ミ ンA（VA）濃度の著しい高值を認めた。タンパク質制 限給餌により、血漿UN濃度は初診時と第40病日で 79.6 $\mathrm{mg} / \mathrm{dl}$ から $15.7 \mathrm{mg} / \mathrm{dl}$ に、血槳 T-chol濃度は $201 \mathrm{mg} / \mathrm{dl}$ から $66 \mathrm{mg} / \mathrm{dl} に そ れ そ ゙ れ$ 著しく減少した。血漿Crea濃度は3.6 $\mathrm{mg} / \mathrm{dl}$ から $2.8 \mathrm{mg} / \mathrm{dl}$ に、血漿 $\mathrm{VA}$ 濃度は4 $483 \mathrm{IU} / \mathrm{dl}$ から 283 IU/dlにとそれぞれ減少したものの、依然高值を示した。 また、血槳カルシウム $(\mathrm{Ca})$ および無機リン ( $\mathrm{iP}$ ) 濃 度は基準值の範囲にあり、経過中に大きな変化はみられ なかった。一方、血槳マグネシウム $(\mathrm{Mg})$ 濃度は経過 に伴い減少した（表３）。また、初診時の血漿 $\mathrm{Na} 、 \mathrm{~K}$ 、 およびCl濃度はそれぞれ146、4.2、および98 $\mathrm{mEq} / 1$ であ り、血漿Cl濃度がやや低值を示した以外は基準值の範囲 であった。

血清エリスロポエチン（Epo）濃度の測定：腎性貧血 を疑い、初診時における血清Epo濃度を抗ヒトエリスロ ポエチン抗体を用いた 2 抗体RIA法（リコンビジョン $\mathrm{EPO}$ キット、(侏三菱化学ヤトロン)により測定した。 対照として月齢の近い臨床症状に異常のない黒毛和種牛 4 頭（8～9 ケ月齢）を用いて比較した。症例の血清 Epo濃度は7.6mU/mlであったのに対し、対照牛は $9.0 \pm$ $1.8 \mathrm{mU} / \mathrm{ml}$ で、症例と対照牛との間に大きな差は認めら れなかった。

尿検查所見：第29病日の尿検査所見では、タンパク質 土、pH7.5、尿比重1.020で、潜血、ケトン体および糖は 陰性であった。

病理所見：病理解剖所見では、腎臓は左右共に表面が 粗造で褐色を呈し、皮質には線状白色斑がび慢性に認め

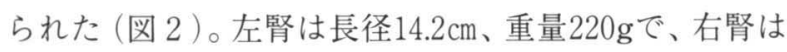
長径 $13.6 \mathrm{~cm}$ 、重量 $215 \mathrm{~g}$ であった。その他の臓器に顕著な 異常は認められなかった。腎臟の病理組織所見では、糸 球体の辺縁不整と基底膜の肥厚、腎尿細管の低形成と囊 胞性拡張、尿細管上皮細胞の脱落などか認められた（図 3 )。

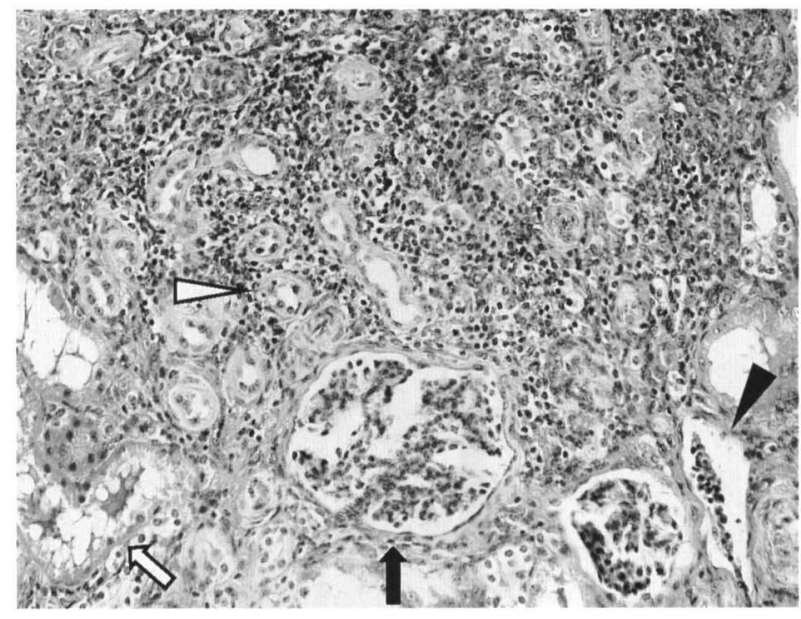

\section{図 3．腎臓の病理組織所見 (HE染色) 黒矢印：糸球体辺縁不整と基底膜の肥厚 白矢印 : 尿細管の囊胞性拡張 黒矢頭 : 尿細管の上皮細胞の脱落 白矢頭 : 尿細管の低形成}

\section{考 察}

牛CL-16欠損症は発生頻度が高く、経済的な影響も大 きいことから多くの研究が抗こなわ扎、その臨床症状、 発病原因抒よび予防法が明らかにされている $[7,8,11$ 14, 17, 19-21]。しかし病態はいまだ不明な点が多く、し ばしばみられる過長蹄や頶血の原因に関する報告はほと んどみられない $[21]$ 。本症例でも軽度の貧血を認めた ため、腎臟で生成される血清Epo值を測定した結果、対 照牛との間に差はみられず、この症例の貧血は腎機能障 害によるEpo分泌障害に起因したものではないことが示 唆されたが、貧血の原因究明には至らなかった。

CL-16欠損症は発症時期が広範囲で、なかには 3 産ま でした繁殖牛の報告もある $[19,20]$ こうした症状の発 現時期と病状の差異に関しては、いわゅる「個体差」と して説明されることが多いが、CL-16欠損症の多くが濃 厚飼料を多給するようになってから臨床徴候を発現する ことから、著者らはタンパク質摂取量の増加が発症時期 や病状に影響を与えているのではないかとの仮説に基づ きタンパク質制限給餌を行った。

その結果、病初にみられた跛行は消失し、血漿UN、 Crea、VA㧍よびT-chol濃度は低下した。跛行の原因お よび跛行が消失した理由は不明であった。血漿UN濃度 の低下は夕ンパク質の摄取量が減少し、その代謝産物で あるUNの産生量が減少したことが大きな要因と考えら れた。血槳 $\mathrm{T}-\mathrm{chol}$ 濃度の隇少も同様に、タンパク質摂取 量および可消化養分総量の減少によると考えられた。

クレアチニンは窒素化合物のうちで最も排泄が容易な 成分で、系球体基底膜を自由に通過し尿細管からの再吸 
収も分泌もなく、このため血清Crea濃度の増加は腎障 害と系球体濾過量の低下を反映する［6］。また、Crea は筋肉中でクレアチンから生成され、その生成量は肝臟 で合成されるクレアチンの量と比例することが知られて おり、肝障害、代謝障害および体重の変動がなければ基 礎生成量は大きく変わらない [6]。本症例では、肝障 害もみられず、タンパク質摂取制限をしたものの体重を 維持するには十分な栄養量を給与しており、体重の変化 はなかった。このことから、血獎Crea濃度の低下は糸 球体濾過率が改善した結果であることが示唆された。

また血清Mg濃度は、給与量が来院前の $18 \mathrm{~g}$ から $9 \mathrm{~g}$ に 減ったことで経過中次第に低下したが、同じ飼料給与量 にも関わらず第30病日以降に血漿UNおよびCreaととも にさらに低下したことは糸球体濾過率の改善を示唆する 成績かもしれない。CL-16欠損症の末期には低Ca血症が しばしばみられる $[11,19,20]$ が、本症例ではCaが必 要量給与され、かつ末期腎でなかったために血獎Ca濃 度は基準值の範囲であったと考えられた。血漿 $\mathrm{P}$ 濃度は CL-16欠損牛では高值を示す $[11,20]$ が、本症例では 当初より基準值の範囲にあり、さらにリン掑取制限によ り増加が抑制された可能性が考えられた。

生体内において、VAの運搬に深く関与するレチノー ル結合蛋白（RBP）はhoro-RBPとしてレチノールを運 搬後、apo-RBPとなり腎系球体から滤過され、そのほと んどは尿細管から再吸収されて尿細管上皮細胞で異化除 去される [9] が、ヒトの慢性腎疾患では糸球体滤過率 の低下や異化除去が減少することで血中VAおよびRBP 濃度が高值を示すことが報告されている [4]。CL-16 欠損症牛でも同様の報告があり [21]、本症例において も血獎VA濃度の著しい高值が認められた。本症例の夕 ンパク質制限給餌中のVA給与量は計算上で日本飼養標 準の充足率を大きく上回っていたにも関わらず、経過中 に血嶈VA濃度は大きく低下した。血墏VAおよびRBP 濃度に正の相関がみられること [21］から、前述のよう に系球体滤過率が改善したことで血漿RBP濃度が低下し、 血漿VA濃度も低下したものと考えられた。しかし、第 40病日での血槳VA濃度が283IU/dlと依然として正常子 牛の上限值 [14] を超えていたことは、血漿Cre濃度の 高値と併せて腎機能が正常でないことを示唆するもので あった。このことは病理組織学的な所見で、尿細管の低 形成、尿細管上皮細胞の変性と剥離、および系球体の辺 縁不整と基底膜の肥厚など、腎組織の異常がみられたこ とからも寒付けられた。

本研究から、CL-16欠損症を発症しても症状が軽度な
症例ではタンパク質制限給飳を行うことで腎機能の低下 を抑制することが示唆された。また今回の症例では、夕 ンパク質を制限したことで結果的にはリン摄取も制限す ることになり、また体重を維持するには十分な栄養を与 えたことと併せて、良好な経過をたどったと考えられた。 今回の成繢は、粗飼料中心で飼育されたCL-16欠損症の 繁殖牛において、初産や 3 産日まで臨床徴候を発現しな かった症例 $[19,20]$ が存在した理由の一部を示唆して いるかもしれない。

本症例でも体重增加がなかったように、増体が求めら れる育成牛や肥育牛においてタンパク質制限給餌は現実 的ではなく推奨されない。また、CL-16欠損症は最終的 に尿毒症により致死的経過をとることから、保因牛同士 の交配を避けて本症の発生を未然に防止することが最も 重要であると考えられる。

稿を終えるにあたり、症例の提供に尽力いただいた福 島県農業共済組合連合会 山野辺浩先生に感謝する。本 研究の一部は、社畜産技術協会DNA育種技術開発実用 化事業委託研究費により実施した。

\section{文 献}

1. Bartola, S. P. and Rutgers, H. C. (1993). 慢性間 質性腎炎：猫の内科学（II）（加藤 元, 大島 慧監 訳), pp.1336-1340, 文永堂出版, 東京.

2. Finco, D. R., Crowell, W. A. and Barsanti, J. A. (1985). Effects of three diets on dogs with induced chronic renal failure. Am. J. Vet. Res. 46 : 646-653.

3. Finco, D. R., Brown, S. A., Crowell, W. A., Dunkan, R. J. Barsanti, J. A. and Bennet, S. E. (1992). Effects of dietary phosphorus and protein in dogs with chronic renal failure. Am. J. Vet. Res. 53 : 1163-1170.

4. Goodman. D. S. 小林 正 訳 (1974). レチノール 結合タンパク質及びビタミンA代謝の栄養学的展望.ビ タミン $48: 495-501$.

5. Jacob, F., Polzin, J. D., Osborne, A. C., Allen, T. A., Kirk, C. A., Neaton, J. D. and Lekcharoensuk, C. (2002). Clinical evaluation of dietary modification for treatment of spontaneous chronic renal failure in dogs. J. Am. Vet. Med. Assoc. 220: 1163-1170.

6. 河合 忠 (1996). クレアチン・クレアチニン：異 常值の出るメカニズム（第 3 版）（河合 忠, 屋形 稔編), pp.106-109, 医学書院, 東京.

7. 北川 均, 鬼頭克也, 大場恵典, 佐々木㮡英 (2005). 
尿細管形成不全:獣医内科学 大動物編（川村清市， 内藤善久, 前出吉光編 $), \quad$ p $.290-292$, 文永堂出版, 東京.

8. 北川 均 (2006). 尿細管形成不全（パラセリン1） クローディン16欠損症)：牛の先天異常（浜名克己編）, pp.16-18, 学空社, 東京.

9. 武藤泰敏 (1980)。レチノール-RBP輸送系の調節と その病態：ビタミン学 I (日本ビタミン学会編), pp. $57-62$, 東京化学同人, 東京.

10，成瀬友彦，渡邊有三（2002）。慢性腎不全における 蛋白制限の効果. 現代医学50：155-158.

11. Ohba, Y., Kitagawa, H., Okura, Y., Kitoh, K. and Sasaki, Y. (2001). Clinical features of renal tubular dysplasia,a new hereditary disease in Japanese Black cattle. Vet. Rec. 149 : 115-118.

12. Ohba, Y., Kitagawa, H., Kitoh, K., Oikawa, T. and Sasaki, Y. (2001). Inheritance of renal tubular dysplasia in Japanese Black cattle. Vet. Rec. 149 : 153-154.

13. Ohta, H., Adachi, H., Takiguchi, M. and Inaba, M. (2006). Restricted localization of Claudin-16 at the tight Junction in the thick ascending limb of Henle's loop together with Claudins 3,4 and 10 in bovine nephrons. J. Vet. Med. Sci. $68: 453-463$.

14. Okada, K., Ishikawa, N., Fujimori, K., Gogyo, M., Ikeda, M., Sasaki, J., Watanabe, D., Takasuga, A., Hirano, T. and Sugimoto, Y. (2005). Abnormal development of dephrons in Claudin-16-defective Japanese black cattle. J. Vet. Med. Sci. 67 : 171-178.

15. Polzin, D. J., Osborne, A. C., Hayden, D. W. and Stevens, J. B. (1983). Effects of modified protein diets in dogs with chronic renal failure. J. Am. Vet. Med. Assoc. 183 : 980-986.

16. 佐中 孜 (2000). 腎不全の食事療法の実際と問題 点. Medical Pratice 17 : 1911-1917.

17. Sasaki, Y., Kitagawa, H., Kitoh, H., Okura, Y., Suzuki, K., Mizukoshi, M., Ohba, Y. and Masegi, T. (2002). Pathological changes of renal tubular dysplasia in Japanese Black cattle. Vet. Rec. 150 : 628-632.

18. 佐藤れえ子（2005）慢性腎不全：獣医内科学 小動 物編 (岩㟝利郎, 辻本 元, 長谷川篤彦編), pp. 266270 ，文永堂出版，東京。

19. 高橋雅博, 草維 純, 瀬田川 清, 斉藤一秋, 太田
和広，藤島信賢，金田郁雄，小松 茂，斎藤幸夫，小 玉 肇，與齊和博，佐藤 司，鈴木敏規 (2001)。秋 田県内に招ける黒毛和種牛クローディン16欠損症の発 生状況について。家畜診療 $46: 379-383$.

20. 渡辺大作, 伴 顕, 高橋雅博, 石川 弘, 渡辺炤夫, 山野辺 浩, 角金俊一, 藤森康一郎, 三宅陽一, 岡田 幸助, 大塚浩通, 小黑雅史, 川村清市, 平野 貢, 杉 本喜憲, 阿部省吾, 齋藤博水 (2002)。東北地方にお ける牛クローディン-16欠損症の遺伝学的調查と臨床 病理学的特徵. 家畜臨床誌 $25: 1-10$.

21. 渡辺大作, 阿部省吾, 植松正巳, 阿部 策, 遠藤祥 子, 後藤浩人, 小林隆之, 藤倉尚士, 小形芳美, 伴 顕, 平野 貴, 杉本喜憲, 齋藤博水 (2004)。腎不全 牛に抢ける過長踇の発現と血清ビタミンAおよびレチ ノール結合蛋白の動態. 家畜臨床誌 $27: 41-45$. 